2. To: (Receiving Organization)

Distribution

5. Proj./Prog./Dept./Div.:

S-Farm Overground Transfer (OGT) Line/Interim Stabilization Project

\section{From: (Originating} Organization)

Interim Stabilization Engineering

6. Design Authority/ Design Agent/Cog. Engr.:

WF Zuroff/FDNW/JN Doeler

\section{Related EDT No.:}

$612794,612795,617982$,

$617983,622129,622130$, 623332

7. Purchase Order No:

N/A

9. Equip./Component No::

N/A

For the S-Farm Overground Transfer (OGT) line between valve pits 241-S-B and $241-S-D$, the attached Installation Instruction addresses the installation of the encasement piping, pipe supports, heat tracing, insulation, leak detectors, temperature indicators and shielding blocks.

11. Receiver Remarks: 11A. Design Baseline Document? $[\mathrm{x}]$ Yes [] No

Approval of the S-Farm Overground Transfer Line Valve Pit 241-S-B to Valve Pit 244441-S-D Installation Instruction is indicated by signature on this EDT.

11.A. Refer to Design Verification for S-Farm Overground Transfer Line, HNF3381, Rev. 0, dated September 1998.
10. System/Bldg./Facility:

TWRS/241-S (OGT)

12. Major Assm. Dwg. No.:

N/A

13. Permit/Permit Application No.:

N/A

14. Required Response Date: March 17, 1998

\begin{tabular}{|c|c|c|c|c|c|c|c|c|c|c|}
\hline 15. & \multicolumn{6}{|c|}{ DATA TRANSMITTED } & (F) & (G) & $(\mathrm{H})$ & (l) \\
\hline $\begin{array}{l}\text { (A) } \\
\text { Item } \\
\text { No. } \\
\end{array}$ & \multicolumn{2}{|c|}{ (B) Document/Drawing No. } & $\begin{array}{l}\text { (C) } \\
\text { Sheet } \\
\text { No. } \\
\end{array}$ & $\begin{array}{l}\text { (D) } \\
\text { Rev. } \\
\text { No. }\end{array}$ & \multicolumn{2}{|c|}{ (E) Title or Description of Data Transmitted } & $\begin{array}{l}\text { Approval } \\
\text { Desig- } \\
\text { nator }\end{array}$ & $\begin{array}{c}\text { Reason } \\
\text { for } \\
\text { Trans- } \\
\text { mittal }\end{array}$ & $\begin{array}{l}\text { Origi- } \\
\text { nator } \\
\text { Dispo- } \\
\text { sition }\end{array}$ & $\begin{array}{l}\text { Receiv- } \\
\text { er } \\
\text { Dispo- } \\
\text { sition } \\
\end{array}$ \\
\hline 1 & \multicolumn{2}{|l|}{ HNF-3479 } & - & 0 & \multicolumn{2}{|c|}{$\begin{array}{l}\text { Installation Instruction for S- } \\
\text { Farm Overground Transfer } \\
\text { System, Valve Pit } 241-S-B \text { to } \\
\text { Valve Pit 241-S-D. }\end{array}$} & $\mathrm{SQ}$ & 1 & 1 & \\
\hline \multicolumn{11}{|c|}{ 16. KEY } \\
\hline \multicolumn{2}{|c|}{ Approval Designator $(F)$} & \multicolumn{4}{|c|}{ Reason for Transmittal (G) } & \multicolumn{5}{|c|}{ Disposition $(\mathrm{H})$ \& (1) } \\
\hline \multicolumn{2}{|c|}{ (Ref: HNF-PRO-233) } & $\begin{array}{l}\text { 1. Ap } \\
\text { 2. Re } \\
\text { 3. Inft }\end{array}$ & \multicolumn{3}{|c|}{$\begin{array}{l}\text { 4. Review } \\
\text { 5. Post-Review } \\
\text { 6. Dist. (Receipt Acknow. Required) }\end{array}$} & $\begin{array}{l}\text { 1. Approved } \\
\text { 2. Approved w/comm } \\
\text { 3. Disapproved w/col }\end{array}$ & & \multicolumn{3}{|c|}{$\begin{array}{l}\text { 4. Reviewed no/comment } \\
\text { 5. Reviewed w/comment } \\
\text { 6. Receipt acknowledged }\end{array}$} \\
\hline
\end{tabular}

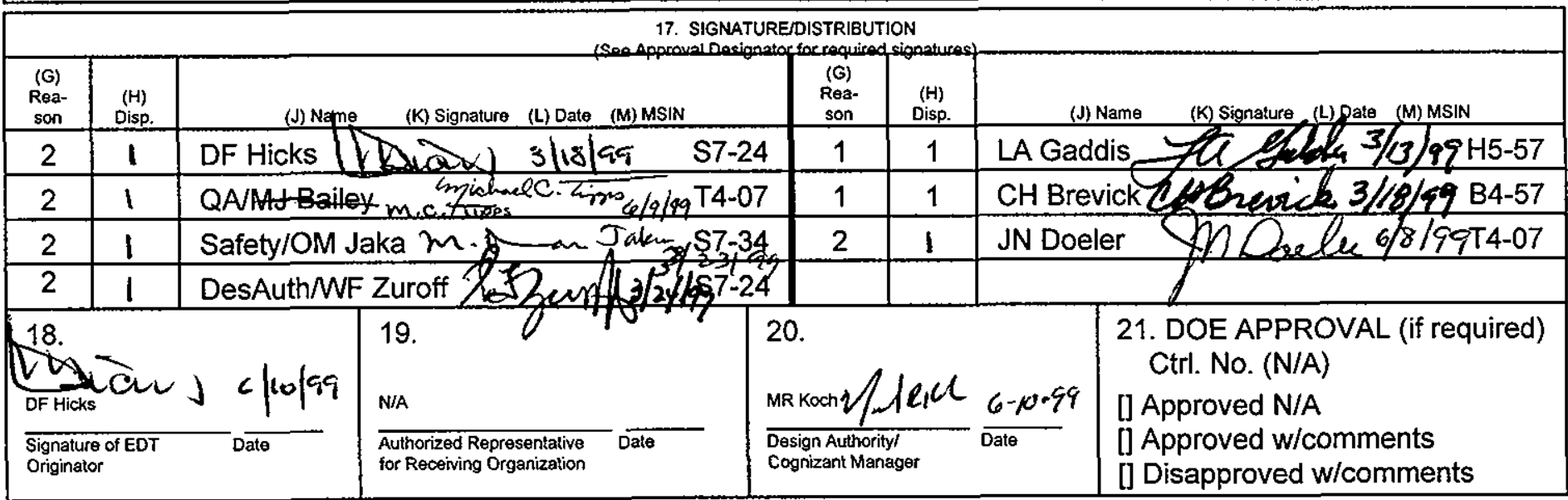

BD-7400-172-2 (05/96) GEF097 
HNF-3479, Rev. 0

\title{
INSTALLATION INSTRUCTIONS
}

\author{
(ETN-98-0005)
}

\section{S-Farm Overground Transfer (OGT) System Valve Pit 241-S-B to Valve Pit 241-S-D}

Dale F. Hicks

Numatec Hanford Corporation, POB 1300, Richland, WA 99352

U.S. Department of Energy Contract DE-AC06-96RL13200

$\begin{array}{llll}\text { EDT/ECN: } & 612796 & \text { UC: } & 721 \\ \text { Org Code: } & 83100 & \text { Charge Code: } & 103360 / \text { EFO0-588/50 } \\ \text { B\&R Code: } & \text { EW3120074 } & \text { Total Pages: } & 12\end{array}$

Key Words: OGT, Overground Transfer, Interim Stabilization, 241-S, 241S-B, 241-S-D, saltwell pumping, Installation Instructions.

Abstract: This document provides the system description and installation instructions for construction of the 241-S overground Transfer (OGT) system, including the sequence of assembly and testing requirements.

* PITTWRAP is a registered trademark of Pittsburgh Corning Corporation.

TRADEMARK DISCLAIMER. Reference herein to any specific comnercial product, process, or service by trade name, trademark, manufacturer, or otherwise, does not necessarily constitute or imply its endorsement, recormendation, or favoring by the United States Government or any agency thereof or its contractors or subcontractors.

Printed in the United States of America. To obtain copies of this document, contact: Document Control Services, P.0. Box 950, Mailstop H6-08, Richland WA 99352, Phone (509) 372-2420; Fax (509) 376-4989.
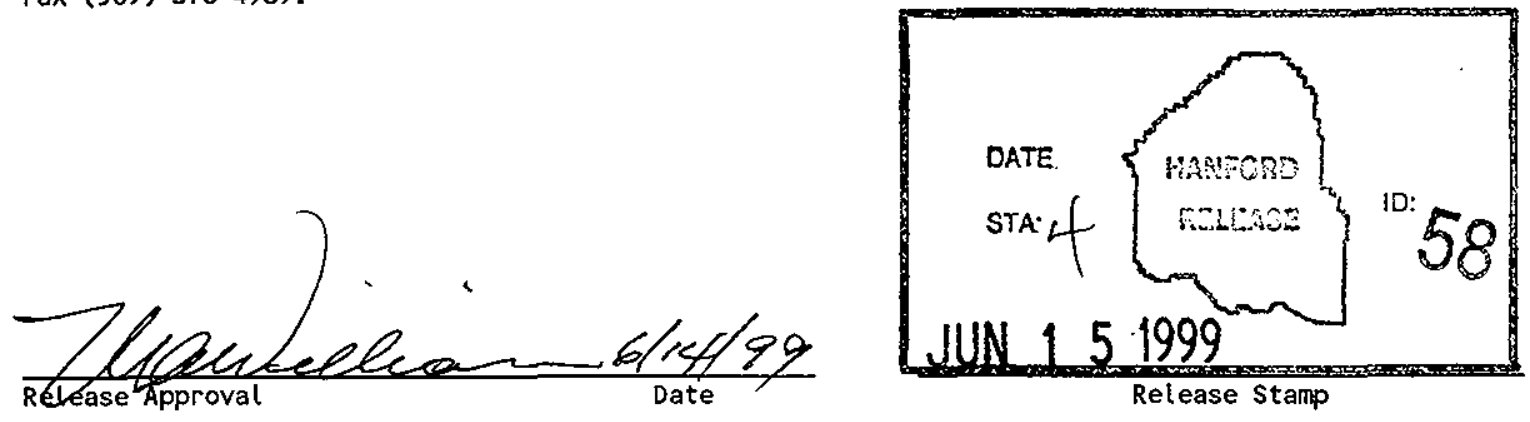

\section{Approved for Public Release}




\section{INSTALLATION INSTRUCTION}

\section{S-FARM OVERGROUND TRANSFER LINE}

VALVE PIT 241-S-B TO VALVE PIT 241-S-D

February 1999 


\title{
INSTALLATION INSTRUCTION
}

\author{
S-FARM OVERGROUND TRANSFER LINE
}

\section{VALVE PIT 241-S-B TO VALVE PIT 241-S-D}

February 1999

\section{FLUOR DANIEL NORTHWEST}
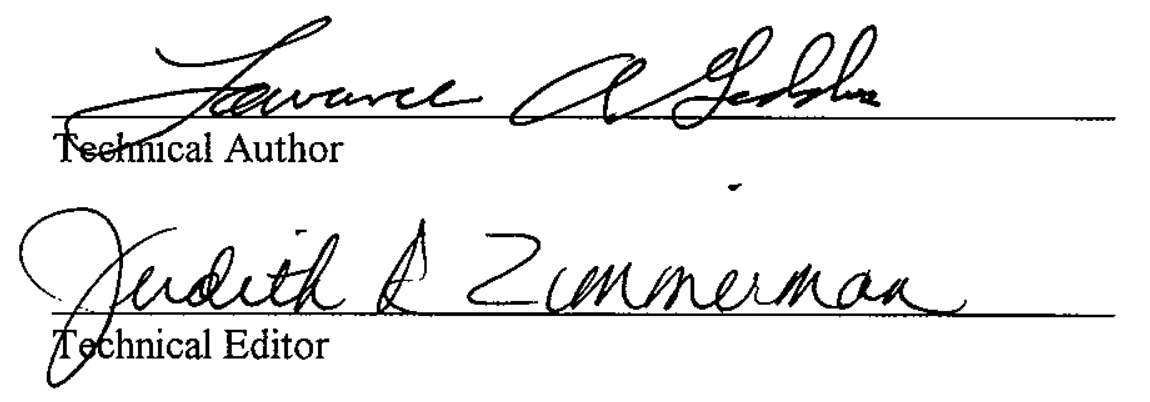

$$
\frac{2 / 8 / 99}{\text { Date }}
$$$$
2 / 8 / 99
$$
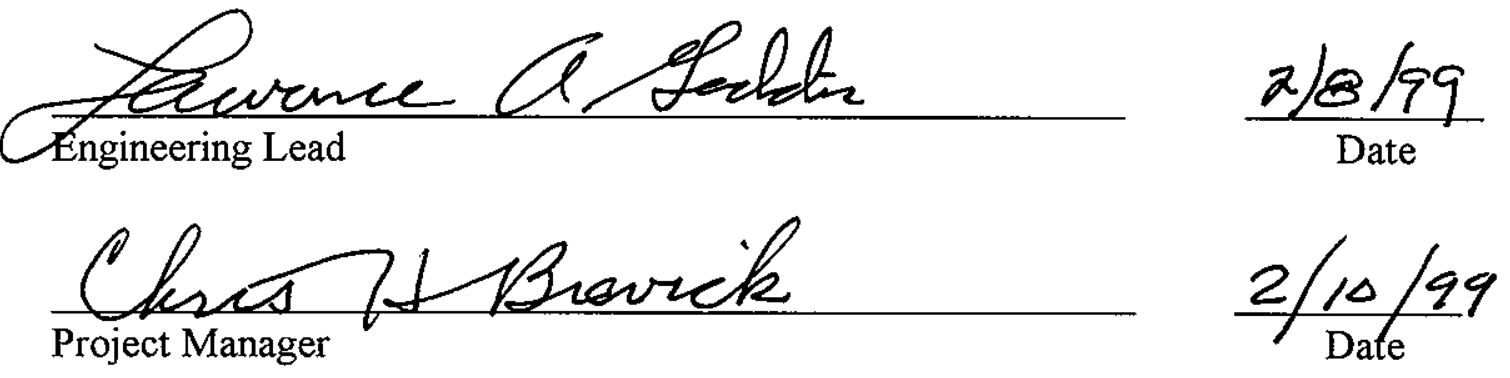

NUMATEC HANFORD CORPORATION
$\frac{1 \text { AQ }}{\text { Project Engineer }}$
$\frac{3 / 18 / 99}{\text { Date }}$ 


\section{TABLE OF CONTENTS}

INTRODUCTION $\ldots \ldots \ldots \ldots \ldots \ldots \ldots \ldots \ldots \ldots \ldots$

SYSTEM DESCRIPTION $\ldots \ldots \ldots \ldots \ldots \ldots \ldots \ldots$

INSTALLATION INSTRUCTION AND PRECAUTION . . . . . . 3

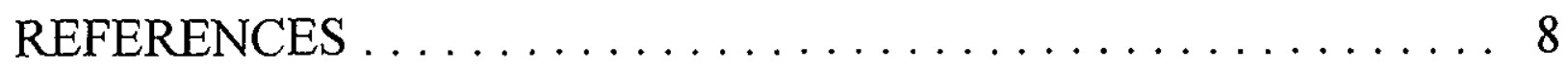


HNF-3479, Rev. 0

\title{
INSTALLATION INSTRUCTION
}

\author{
S-FARM \\ OVERGROUND TRANSFER LINE
}

\section{VALVE PIT 241-S-B TO VALVE PIT 241-S-D}

\subsection{INTRODUCTION}

Lockheed Martin Hanford Corporation (LMHC) is providing an overground transfer (OGT) system for use in saltwell pumping of the 241-S-Tank Farm. Fluor Daniel Northwest (FDNW) was requested to support the effort by completing the design of the OGT system and completing the construction of the encasement pipe and encasement pipe support system. FDNW will also install the concrete shielding blocks for the OGT system. The shielding block system will provide a vehicle barrier for protection of the OGT line and will provide a radiation barrier for operations personnel. LMHC is responsible for the regulatory compliance of the entire transfer system.

This installation instruction covers the encasement piping, pipe supports, heat tracing, thermal insulation, leak detectors, temperature indicators, and the shielding blocks. Installation of the primary (inner) pipe and associated equipment was completed at a previous time and the integrity of the primary piping will be confirmed by LMHC prior to operation of the system.

\subsection{SYSTEM DESCRIPTION}

\subsection{Overground Transfer System}

The OGT system is for periodic waste transfers required for waste management of the 241-S Tank Farm and other authorized interim stabilization activities. Pumping will be accomplished using the temporary OGT piping system. The encasement piping takes the most direct route possible from valve pit 241-S-B to valve pit 241-S-D (ref. drawing $\mathrm{H}-2-829564$, sh 1). The 75-mm (3-in.) stainless steel encasement piping slopes from valve pit $241-\mathrm{S}-\mathrm{B}$ toward valve pit $241-\mathrm{S}-\mathrm{D}$. Flange connection pipe spool assemblies allow for 
ease in installation and future decontamination, disassembly, and reuse or demolition (ref. drawing H-2-818280, sh. 1). The length of the system is approximately $54-\mathrm{m}$ (178-ft).

\subsection{Pipe Supports}

Adjustable pipe supports keep the transfer line uniformly sloped over the irregular ground. The supports are capable of providing support for the encasement pipe and the EPDM hose (primary pipe). The pipe support assemblies are shown on reference drawings $\mathrm{H}-2-829564$, sh 1 and 2.

\subsection{Leak Detectors}

Leak detection instrumentation is installed at both ends of the OGT encasement system to detect the presence of leaked waste in the encasement pipe. The leak detector element is located at each end of the encasement pipe and the system is capable of detecting the presence of approximately $0.15 \mathrm{~L}$ ( $9 \mathrm{cu}$. in.) of waste. The leak detector assembly is shown on reference drawing H-2-829564, sh 2.

\subsection{Heat Tracing, Temperature Sensors, and Insulation}

Heat tracing, temperature sensors, and insulation materials are installed following installation of the OGT system piping, but before the shielding blocks are installed. The heat trace is capable of maintaining the encasement pipe at $45^{\circ} \mathrm{C}\left(113^{\circ} \mathrm{F}\right)$ at a $-23^{\circ} \mathrm{C}$ $\left(-10^{\circ} \mathrm{F}\right)$ ambient temperature.

Heat trace is self-regulating, maximum maintenance temperature of $45^{\circ} \mathrm{C}\left(113^{\circ} \mathrm{F}\right)$, and is rated for 12 watts/foot (maximum) at $120 \mathrm{VAC}$. There are two heat trace cable circuits on the OGT encasement, each with two parallel cables. One cable on each circuit is a spare and is intended to be used only if the active cable fails.

Digital thermometers mounted on the outside of the shielding blocks and thermocouple assemblies attached to each end of the encasement pipe will provide visual confirmation of the OGT line temperature. 
The molded, sectional, cellular-glass pipe insulation meets the requirements of ASTM C552, complete with factory-applied jacketing similar to Pittsburgh Corning foam glass with PITTWRAP pre-jacketing.

Heat tracing, temperature indicators, and insulation details are shown on reference drawings H-2-829566, sh 1 and 2 and H-2-829564, sh 1.

\subsection{Shielding Blocks}

Precast concrete shielding blocks are being used to provide a vehicle barrier for protection of the OGT, and the blocks will also provide a radiation barrier to support ALARA. The shielding blocks are coated with a special protective coating to allow for decontamination after use. Shielding block details are shown on reference drawing H-14-100414, sh 1, 2, and 3 .

The shielding blocks are emplaced over the OGT pipe after completion of the encasement pipe, pipe supports, leak detection, heat tracing, and insulation. Shielding block placement is shown on reference drawings $\mathrm{H}-2-829565$, sh 1 and 2.

\subsection{INSTALLATION INSTRUCTION AND PRECAUTION}

\subsection{Installation Sequence}

The OGT system installation sequence is described in steps below:

- Step 1 Installation of the encasement pipe.

- Step 2 Installation of the pipe supports.

- Step 3 Installation of leak detectors.

- Step 4 Verify alignment of OGT pipe line (FDNW Survey).

- Step 5 Pneumatic testing of encasement pipe. 
- Step 6 Installation and testing of heat tracing and temperature sensor

- Step 7 Installation of insulation material and testing of heat tracing.

- Step 8 Starting up of heat tracing; demonstrate maintenance of the encasement pipe temperature at $+/-5^{\circ} \mathrm{C}\left(10^{\circ} \mathrm{F}\right)$ of process fluid temperature.

- Step 9 Verify finish grade for shielding blocks (FDNW Survey).

- Step 10 Placement of shielding blocks.

NOTE:Installation of 25 -mm (1-in.) primary pipe (EPDM hose) is done as a part of Steps 1,2, and 3. Installation of primary pipe is not within the scope of this instruction.

\subsection{Installation of the Encasement Pipe}

Installation of the 241-S Tank Farm OGT encasement pipe is shown on reference drawings $\mathrm{H}-2-829564$, sh 1 and 2. The pipeline location and profile grade is shown on reference drawing $\mathrm{H}-2-829564$, sh 1 with related details shown on reference drawings $\mathrm{H}-2-829564$, sh 1 and 2. The 241-S Tank Farm OGT encasement pipe is approximately 178- $\mathrm{ft}(54-\mathrm{m})$ long with a 9-ft (3-m) jog between southeast corner of valve pit 241-S-B and the northwest corner of valve pit 241-S-D.

The OGT system was intended for various tank farm uses and application of various lengths. To allow for the different alternatives, pipe spool assemblies were fabricated in various length and configurations (ref. drawing H-2-818280, sh 1). For the 241-S Tank Farm encasement pipe application, the assembly numbers are listed on the profile and their respectful lengths are identified in Table $\mathrm{A}$, all shown on reference drawing H-2-829564, sh 1.

Attached to each end of the encasement pipe is a pit entry spool piece, (Assembly 42) at each valve pit. This assembly also allows for connections to the primary piping, attachment of the pneumatic testing assembly, pit entry, attachment to other process lines in the valve pit, and the leak detector and drain of the encasement pipe. 


\subsection{Installation of Encasement Pipe Supports}

The encasement pipe support assembly for the 241-S Tank Farm OGT will be placed at locations as shown on reference drawing $\mathrm{H}-2-829564$, sh 1 . The supports typically will be placed before and after each bend and should be approximately $0.3-\mathrm{m}(1-\mathrm{ft})$ from bend flange. The maximum spacing between supports is $3.0-\mathrm{m}(10-\mathrm{ft})$.

The concrete foundation block will be placed on level, undisturbed, or compacted finish grade. The length of the pipe support legs is variable and after the pipeline has been adjusted to final alignment, the legs will be cut off below the top of the pipe to avoid any interference with the shielding blocks.

A supplemental support, required to provide restraint for lateral forces, is located at station $0+35$ (ref. drawing H-2-829564, sh 2). This support has a longer cross member (685-mm (27-in.)) with base plates on each end. After the shielding block has been placed, the lateral base plates will be adjusted (slid along the Unistrut) to fit snugly against the inside of the shielding block walls. Each base plate is secured to the cross member using a $12-\mathrm{mm}(1 / 2-\mathrm{in}$.) bolt and channel nut to maintain the proper restraint position.

\subsection{Supports at Valve Pits}

A pit entry spool piece is attached to each end of the encasement pipe. The concrete wall of valve pits 241-S-B and 241-S-D supports these entry spool pieces laterally and vertically. The pit entry spool piece (Assembly 42) and the spool piece support (Assembly 40) are shown on drawing H-2-818280, sh 1, Rev. 1. Like other parts of the OGT, these assemblies are intended for use in many applications.

The pit entry spool piece at valve pit 241-S-D will be installed and anchored as originally detailed on the ECNs. The pit entry spool piece at pit 241-S-B will be installed similar to the original details with the modification shown on reference drawing H-2-829564, sh 2. The modification adds backing nuts on the opposite side of the retainer plate, or a spacer between the retainer plates, so that the retainer plates will remain fixed but will allow the spool piece to slide within the support. This ability to move allows for thermo-expansion and contraction of the OGT pipeline. 


\subsection{Installation of Leak Detectors}

Two leak detectors will be installed, one at each end of the encasement pipe within the confines of the pump pits (ref. drawings H-2-829564, sh 2 and H-2-829566, sh 1).

Installation of leak detector power and signal wiring to the pump controller is not within the scope of this instruction.

\subsection{Survey}

After installation of the leak detectors, determine the pipe's location using standard surveying practices under the supervision of a registered land surveyor. Note: vertical alignment is critical because of the minimal slope of the pipe.

\subsection{Pneumatic Testing of Encasement Pipe}

After installation of the pipe supports, mount Assembly 26 - pneumatic testing assembly on Assembly 42 for pneumatic testing of the encasement pipe. The encasement pipe will be pneumatically tested at a test pressure of $172 \mathrm{kPa}(25 \mathrm{psig}) \pm 21 \mathrm{kPa}$ (3 psig).

Pressurization of the primary pipe is not required. For Assemblies 42 and 26, reference drawing H-2-818280, sh 1, Rev. 0.

The duration of the test shall be at least 30 minutes, with no visible leaks or drop in test pressure, and for such additional time as may be necessary to conduct examination for leakage. Refer to FDNW practice 134-500-8223, Flushing and Pressure Testing, for other requirements.

Note: Flushing of the 241-S Tank Farm OGT encasement pipeline is not required.

\subsection{Installation of Heat Tracing}

Install and test Thermon TSX 12-1 heat trace cable, temperature sensor and display, and associated components in accordance with the manufacturer's installation instructions and details shown on reference drawings H-2-829566, sh 1 and 2. 


\subsection{Installation of Insulation Material}

For installation of insulation materials, refer to reference drawing H-2-829564, sh 1 and to the manufacturer's installation recommendations.

\subsection{Installation of Shielding Blocks}

Prior to installation of the shielding blocks, the existing soil grade shall to be adjusted and leveled for proper clearance and placement of the blocks (refer to finished grade profile on reference drawing H-2-829565, sh 1). Some minor excavation (less than 75-mm (3-in.)) and fill (less than 150-mm (6-in.)) will be required to bring the existing ground to final grade. Any disturbed soil or newly placed gravel fill (crushed surfacing top course) will be compacted prior to placement of the shielding blocks. Compaction of the material will require a minimum of two passes over the full width of the sectional area with a vibratory plate compactor. Moisture will be added to ensure a maximum compactive effort. Additional moisture and compaction may be required as determined by the engineer.

The shielding blocks will be emplaced as shown on reference drawing H-2-829565, sh 1 . The blocks should be centered approximately on the OGT line, except the 1.4-m (4.5-ft) shielding block at station $1+12$. This block is to be offset to the west of the OGT line so that access to the dry well riser is not impaired. Adjacent blocks to the offset block should be butted snugly to the offset block to minimize the gap between the blocks. Lead blankets shall be placed over these gaps. Shielding blocks at the valve pits, the elbows, and at the offset should be placed first to allow some flexibility in placement of other blocks. The maximum spacing between any part of the cover blocks is approximately $0.3-\mathrm{m}(1-\mathrm{ft})$.

Placement of the shielding block, the crane's location, and the location of the truck/trailer transporting the shielding block will be in accordance with DOE-RL-92-36, Hanford Site Hoisting and Rigging Manual; the approved job-specific critical lift procedure; and report, Dome Loading on Tanks 241-S-104 and -107 During Proposed Placement of Overground Transfer Pipe Shielding - Revised Evaluation. 


\subsection{REFERENCES}

4.1 Supporting Document, HNF-SD-WM-BIO-001, Rev. 0-K, Tank Waste Remediation System Basis for Interim Operation, August 1998.

4.2 FDNW practice 134-500-8223, Flushing and Pressure Testing.

4.3 DOE-RL-92-36, Hanford Site Hoisting and Rigging Manual, June 26, 1998.

4.4 FDNW Document, Critical Lift Procedure for Installing Shielding Blocks Above Overground Transfer Line, in Job Control System Package WS-95-00163/M, September 9, 1998.

4.5 Lockheed Martin Hanford Company, Interoffice Memo, 74731-98-LJJ-032, Operational Equipment Engineering to R. E. Larson, Dome Loading of Tanks 241-S-104 and -107 During Proposed Placement of Overground Transfer Pipe Shielding - Revised Evaluation, August 11, 1998.

4.6 Drawings

H-2-829564, sh 1 \& 2, Rev. 1, Civil/Piping - 241-S OGT Pipeline H-2-829565, sh 1 \& 2, Rev. 1, Civil/Piping - 241-S OGT Shielding H-2-829566, sh $1 \&$ 2, Rev. 1, Electrical/I \& C-241-S OGT Pipeline H-2-818280, sh 1, Rev. 1, Piping - Overground Transfer System - Assemblies H-14-100414, sh 1, 2, \& 3, Rev. 1, Civil - Concrete Shielding 
DISTRIBUTION SHEET

\begin{tabular}{l|l|l|}
\hline To $\begin{array}{l}\text { Distribution } \\
\text { Droject Title/Work Order }\end{array}$ & $\begin{array}{l}\text { From } \\
\text { Interim Stabilization } \\
\text { Engineering }\end{array}$ & Date $03 / 18 / 99$ \\
\hline \begin{tabular}{l} 
S-Farm Overground Transfer (OGT) Line/103360/EF00-588/50 \\
\hline
\end{tabular} & EDT No. 612796 \\
\cline { 2 - 2 } & ECN No. N/A \\
\hline
\end{tabular}

\begin{tabular}{c|c|c|c|c|c}
\hline & Name & $\begin{array}{c}\text { Text } \\
\text { With } \\
\text { All } \\
\text { Attach. }\end{array}$ & $\begin{array}{c}\text { Text } \\
\text { Only }\end{array}$ & $\begin{array}{c}\text { Attach./ } \\
\text { Appendix } \\
\text { Only }\end{array}$ & $\begin{array}{c}\text { EDT/ECN } \\
\text { Only }\end{array}$ \\
\hline
\end{tabular}

Bailey, Mel J. Brevick, Chris H. Crawford, Jim A. Doeler, Jeff $\mathrm{N}$. Ellingson, Kelly Gaddis, Larry A. Hicks, Dale F. Hissong, Terry L. Holbrook, Doug S. Hu11, Kevin J. Jaka, Omar M. Janicek, George P. Koch, Mike R. Larson, Rich E. McDonald, J. Dan Miller, Phil C. Nguyen, Toan $\mathrm{H}$. Raven, Bexa P. Saueressig, Dave J. Swarers, Tom A.

Tipps, Mike C.

T4-07

B4-57

S7-24

T4-07

S7-24

H5-57

S7-24

S7-24

S5-50

T4-07

S7-34

S7-12

S7-24

T4-07

S7-24

R1-51

S7-24

S7-24

S7-24

S7-24

S7-34

True, Roger R.

Volkman, Terry $J$.

Vladimiroff, David T.

T4-07

T4-07

S7-24

Wiatrak, Sharon L.

S7-24

Wiggins, Dirk D.

Wiggins, J. Dewayne

Zuroff, Bill F.

DOE-RL Reading Room

FDNW TDC

S7-24

S7-24

S7-24

$\mathrm{H} 2-55$

E6-02

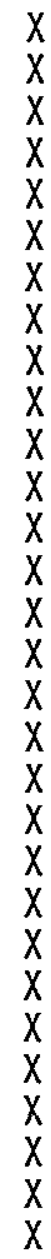

